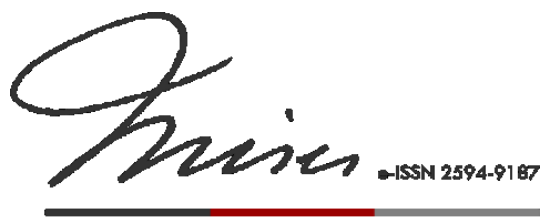

MISES: Interdisciplinary Journal of Philosophy, Law and Economics
Disponível em www.misesjournal.org.br

MISES: Interdiscip. J. of Philos. Law and Econ, São Paulo, 2018; 6 (2) e-ISSN 2594-9187

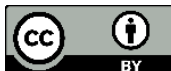

\title{
Editorial:
}

\section{Novos elos para novos horizontes}

\section{Adriano de C. Paranaiba - Instituto Federal de Goiás (IFG) - paranaiba@mises.org.br}

É muito comum utilizarmos a palavra 'corrente' para apontar uma escola de pensamento. Assim, o termo 'correntes de pensamento' acabam sendo mais comum que a ideia de escola, pois transmite à mente o conceito de laços ou elos que se encadeiam para compor e dar forma a um conjunto de ideias. Neste tocante, a consolidação recente da Escola Austríaca no Brasil aponta para a história de pessoas que, como elos, foram se encadeando para a construção e disseminação das ideias de Menger, Böhm-Bawerk, Mises e Hayek no território nacional.

Essa edição é marcada pela concretização de parcerias em projetos que colheram importantes conquistas. A publicação de artigos científicos e resenhas, frutos destas parcerias, de fato, substancializam a ideia de novos elos para a construção desta corrente de pensamento, que é a Escola Austríaca de Economia no Brasil.

A seção Artigos de Pesquisa nos brinda com três artigos selecionados pela organização do I Fórum Mackenzie de Liberdade Econômica, realizado entre os dias 6 e 8 de novembro de 2017, promovido pelo Centro Mackenzie de Liberdade Econômica. O objetivo de evento, que em 2017 teve sua primeira edição, é a mobilização e o compartilhamento de experiências práticas exitosas entre empresários, pesquisadores, professores, estudantes e organizações não-governamentais interessados no tema da livre iniciativa. O primeiro artigo, de autoria dos professores doutores Adilson Caldeira, Alberto de Medeiros Jr. e Gilberto Perez apresenta um diagnóstico minucioso sobre os fatores relativos à inovação que influenciam a competitividade do setor têxtil brasileiro. $O$ segundo constructo selecionado é de autoria da discente da pós-graduação em Escola Austríaca, Mariangela Ghizellini, sobre os impactos do intervencionismo causado pela legislação urbana, especificamente no caso dos casarões de bairros nobres da cidade de São Paulo. O terceiro artigo selecionado avalia a concessão de créditos pelo BNDES em uma ótica do direito e é assinado por André Lustosa Rege Botelho. 
Essa seção também é composta por mais quatro artigos de autores que submeteram suas pesquisas para o fluxo editorial do periódico. Gabriela Bratz Lamb apresenta os efeitos indesejados da intervenção e protecionismo na indústria bélica nacional. O professor Bruno Gonçalves Rocha realiza uma releitura da história política brasileira com uma ótica libertária, comum à Escola Austríaca. Em seguida, o artigo de Paulo Hora Andrade III aborda a desomogeneização intelectual de Mises e Hayek, nos apresentando a riqueza epistemológica da Escola Austríaca de Economia. Concluindo a seção, a publicação do artigo apresentado por este editor no Austrian Economics Research Conference (AERC), realizado em março de 2017 no Mises Institute, Auburn, Alabama. O artigo trata da articulação epistemológica entre Praxiologia e a Teoria da Sintaxe Espacial, na análise da mobilidade urbana.

Seguindo o fortalecimento das parcerias, a seção Ensaios \& Insights traz os artigos vencedores do concurso "Como privatizar os Correios". O concurso organizado pela Rede Liberdade, foi apoiado pelo Instituto Mises Brasil, Centro Mackenzie de Liberdade Econômica e o Instituto Liberal de São Paulo (ILISP). O objetivo foi estimular a produção intelectual e reconhecer as pesquisas que apresentem fundamentação teórica e proposição de soluções para o tema central do concurso. Foram mais de 70 inscrições, superando todas as expectativas. Seis pareceristas fizeram parte da comissão julgadora de modo a garantir que todos os artigos fossem avaliados imparcialmente. Os vencedores foram: primeiro lugar: Daniel Bastos Gasparotto; segundo lugar: Marcelo de Arruda e terceiro lugar: Odair Desters. Conforme previsto em edital, uma menção honrosa foi concedida ao artigo de autoria de Francisco Martins Loenert. Cada um desses trabalhos traz uma abordagem de propostas para a privatização e abertura do mercado que atualmente é um monopólio estatal.

Mantendo a política de traduções de publicações de pensadores da Escola Austríaca, nesta edição trazemos o artigo de Ludwig van den Hauwe "John Maynard Keynes and Ludwig von Mises on Probability", originalmente publicado em inglês no volume 22 do Journal of Libertarian Studies, em 2011. O texto apresenta as nuances entre os pontos de vista sobre o uso de probabilidade nas ciências sociais por Keynes, Ludwig von Mises e seu irmão, Richard von Mises, matemático cujas contribuições são muito relevantes para a teoria da probabilidade.

Por fim, a seção de Resenhas também traz frutos de uma nova parceria entre este periódico, a Editora LVM e o grupo de estudos Clube Bastiat, com atividades em Goiás. A Editora LVM realizou a doação de livros da Coleção von Mises e o Clube Bastiat promoveu um concurso de resenhas, sendo que as três vencedoras podem ser conferidas nesta edição. 
Mais que desejar uma boa leitura, esta edição apresenta novos elos que foram surgindo e seus resultados na publicação acadêmica. A obra de Jón Gunnar Árnason, Sun Voyager, que ilustra a capa desta edição, representa uma promessa de um território não descoberto, o navegar em busca de progresso e liberdade. Tudo nos sugere que mais elos, certamente, surgirão num futuro próspero no horizonte desta importante corrente de pensamento. 